\title{
Sickle Cell Disease in Sub-Saharan Africa
}

\author{
Thomas N Williams, MBBS, DCH, DTM\&H, MRCP, PhD
}

Imperial College of Science Technology and Medicine, St Mary's Hospital, London W21N, United Kingdom; KEMRI/Wellcome Trust Research Programme, PO Box 230 Kilifi, Kenya

\section{Synopsis}

In Africa, at least 240,000 children are born each year with sickle cell disease. Historically, in the absence of newborn screening and appropriate treatment, the majority of such children died undiagnosed in early childhood. However, with increasing awareness of the condition and economic and epidemiological transition increasing numbers are surviving. In recent decades, much has been learnt about the pathogenesis and treatment of sickle cell disease in North America and Europe. Nevertheless, it cannot be assumed that all these lessons apply to affected subjects in Africa, who face specific economic, social, health and environmental challenges. Greater investments in basic and applied research in the African context, and increased sensitization or African ministries of health regarding the importance of this condition, could make a substantial difference to the lives and livelihoods of millions of people living with sickle cell disease on the continent and their families.

\section{Keywords}

Sickle cell disease; Africa

\section{Introduction}

Sickle hemoglobin $(\mathrm{HbS})$ is a structural variant of normal adult hemoglobin $\left(\mathrm{HbA} ; \mathrm{a}_{2} \beta_{2}\right)$ in which the normal $\beta$ globin subunit is replaced by a mutant form of the molecule $\left(\beta^{S}\right)$ in which the glutamic acid residue normally present at position 6 is replaced by a valine residue, the result of a single nucleotide polymorphism (thymine to adenine; rs334) at position 17 of the $H B B$ gene $^{1}$. This abnormal $\mathrm{HbS}$ polymerizes reversibly under low oxygen tension, and alterations to the shape, rheological and membrane properties of the red blood cells that result from these polymerization events are central to the pathophysiology of the resultant disease ${ }^{2}$. The term "sickle cell disease" (SCD) refers to a heterogeneous group of conditions in which HbS predominates. The most common form of SCD results from the homozygous inheritance of the $\beta^{\mathrm{S}}$-mutation, a condition most referred to as either "HbSS" or "sickle cell anemia" (SCA). While SCA is responsible for at least 70\% of SCD globally, ${ }^{3}$ $\mathrm{SCD}$ can also result from compound heterozygosity for $\mathrm{HbS}$ in association with a wide range of other $H B B$ mutations, including that which results in the production of another structural variant, $\beta^{C}(\mathrm{HbSC})$ and one of the many $\beta$-thalassemia mutations that lead to the 
reduced production of normal $\beta$-globin $\left(\mathrm{HbS} / \beta\right.$-thalassemia). ${ }^{4}$ While the geographic range of $\mathrm{HbS}$ extends throughout most of sub-Saharan Africa (SSA) north of the Zambezi river, both $\mathrm{HbC}$ and $\beta$-thalassemia are confined to more limited parts of West Africa and to the historic trade routes North Africa. As a result, HbSS is by far the most significant form of SCD in SSA, and the form of SCD about which most is known. HbSS is therefore the main focus of the current review.

\section{Origins of the sickle mutation}

Haplotype analysis suggests that the rs334 allele that encodes for $\beta^{\mathrm{s}}$ has arisen, and been independently amplified to its current population frequencies, on at least two and likely more occasions ${ }^{5,6}$. Despite being detrimental in its homozygous form (HbSS) the rs334 allele has reached high population frequencies throughout much of SSA to the extent that through much of the continent more than $15 \%$ of the population are heterozygotes (HbAS; sickle cell trait), notably more than twice that in small surveys from selected populations ${ }^{7}$. That such high heterozygote frequencies might result from selection for HbAS through a survival advantage against malaria was first suggested over six decades ago ${ }^{8}$ and, despite some early skepticism, this hypothesis has since been confirmed far beyond any reasonable doubt (reviewed in reference ${ }^{9}$ ). In a recent meta-analysis of available data from 44 studies conducted throughout the continent, Taylor and colleagues estimated that children with HbAS are more than $90 \%$ less likely to develop severe and complicated $P$. falciparum malaria, the form of malaria associated with the majority of deaths, than normal children with $\mathrm{HbAA}^{10}$. This conclusion has recently been re-affirmed in the most substantial study of its kind conducted to date, involving almost 12,000 case children with severe malaria and more than 17,000 controls recruited from 12 sites throughout the malaria-endemic world, in which the odds ratio (OR) for severe malaria among HbAS children was 0.14 and was associated with a significance level rarely seen in such studies $\left(P=1.6 \times 10^{-225}\right)^{11}$. Moreover, the effect of HbAS is not limited to the most severe forms of malaria but also extends to protection against uncomplicated forms of the disease ${ }^{10}$, with the result that HbAS confers even wider health benefits and survival advantages by protecting against the longer term consequences of uncomplicated malaria such as chronic anemia ${ }^{12}$, malnutrition ${ }^{12,13}$ and invasive bacterial infections ${ }^{14,15}$.

The precise mechanism by which $\mathrm{HbS}$ protects against malaria remains a subject of some speculation. Early work suggested that erythrocytes containing $\mathrm{HbS}$ might be less supportive of $P$. falciparum growth and multiplication than normal red cells under low oxygen tension ${ }^{16-19}$ but more recently it has been suggested that $\mathrm{HbS}$ might protect against malaria by mediating the reduced display of the parasite-encoded protein $P$. falciparum Erythrocyte Membrane Protein-1 (PfEMP1) on the surface of malaria-infected erythrocytes. ${ }^{20,21}$ The adherence of $P$. falciparum-infected red blood cells to capillary endothelium has been implicated in both the pathogenesis of severe malaria and in the evasion of parasite-infected red blood cells from immunological removal by the spleen, and so it has been speculated that reduced PfEMP1 display might result in both fewer pathological consequences and in improved clearance of infected red cells during malaria infections. ${ }^{20}$ Finally, it has also been suggested that parasite-infected $\mathrm{HbS}$-containing erythrocytes may be removed more rapidly 
from circulation through innate or acquired immune-mediated processes, ${ }^{16,22-24}$ a process that might also result in their premature destruction by the spleen. ${ }^{16,25}$

\section{SCD in sub-Saharan Africa}

The corollary of positive selection for HbAS through a survival advantage against malaria is that a small but variable proportion of children in malaria-endemic parts of SSA are born with either HbSS or with compound heterozygosity for both $\mathrm{HbS}$ and a second mutation that, together with $\mathrm{HbS}$, results in SCD, the most notable being $\mathrm{HbSC}$ and $\mathrm{HbS} / \beta$ thalassemia. Nevertheless historically, SCD has been profoundly neglected in the African context and even today our knowledge of a whole range of basic facts regarding the condition within the region falls decades behind that for regions where SCD is considerably less common.

Despite the publication of a growing number of reports on the prevalence and distribution of the sickle cell trait in Africa towards the middle of the last century, SCD was rarely recognized by physicians on the continent even 40 years after the condition was first described in the USA ${ }^{26}$. This remarkable observation even led some to question whether the mode of inheritance of SCD might be different in the African context ${ }^{27}$. Even today, in the absence of newborn screening across much of the continent, there are no accurate up-to-date figures regarding the survival rates for SCD in SSA, but by analyzing population data on the age-specific prevalence of SCA, an indirect measure of the loss through death of subjects with this condition, we recently concluded that under-5 mortality among children born with SCA in SSA remains unacceptably high at between $50 \%$ and $90 \%{ }^{28}$. These figures are in stark contrast to those from the North, where in recent years many countries have adopted universal screening for SCD and where most now provide comprehensive care for affected individuals. As a result, mortality is now rare among children born with SCD in Europe, the USA and the Caribbean where the majority of affected children can expect to live to their 40s and 50s ${ }^{29-31}$.

Because official statistics are so poor, even basic facts such as the number of births of children with SCD in Africa can only be estimated using indirect approaches. For example, we recently used a geo-statistical model that combined data on the population frequencies of HbAS from the published and unpublished literature and birth rates and population densities based on United Nations figures, to estimate birth rates for SCA (which accounts for approximately $70 \%$ of SCD) for every country in the world. We concluded that 312,000 (294,000-330,000) children were born with SCA globally in 2010, that almost eighty percent of these children were born in SSA and that half were born in just three countries: Nigeria, the Democratic Republic of Congo and India ${ }^{32}$ (Figure 1). Nevertheless, the veracity of these estimates is undermined by the paucity of data on which they are based, and given high rates of consanguinity in many parts of the region the true numbers could be substantially larger. In combination, the high number of affected births and the high rate of early mortality mean that SCD is probably responsible for upwards of $6 \%$ of all child deaths in many parts of $\mathrm{SSA}^{3}$. 


\section{The natural history of SCD in Africa}

When the very high birth and death rates for children with SCD in Africa are considered, it is notable how poorly the natural history of the condition has been documented on the continent. Despite the fact that almost $80 \%$ of SCD births occur in SSA (Figure 1), academic research from the continent lags far behind that from the North. Less than seven percent of all papers published on the subject since 1940 have included the word "Africa", and even today, research output on SCD from Africa is at a similar level to that of the North from more than 60 years ago (Figure 2). Until very recently, there have been no programs for newborn screening, and no comprehensive studies of the natural history of SCD in Africa have been undertaken. As a result, the common causes of death among children with SCD on the continent have remained a matter of speculation, although it is likely that a substantial proportion of deaths will have been attributable to just two conditions: malaria and invasive bacterial infections.

\section{Malaria}

While it has frequently been assumed that malaria is a common cause for death in African patients with SCD, few solid data are available on which to base this conclusion.

In light of the protective effects of $\mathrm{HbS}$ against malaria, which appears to be directly proportional to the intracellular concentrations of $\mathrm{HbS}$ in heterozygotes ${ }^{33}$, it might be expected that homozygotes would be even more protected. However, there are also reasons why malaria might cause more problems in patients with SCD than in normal subjects. For example, the marked reticulocytosis seen in such patients might increase the efficiency of infection by $P$. falciparum parasites, which show a preference for the youngest, most metabolically active red blood cells ${ }^{34}$. Moreover, the characteristic hyposplenia seen in patients with SCA could lead to reduced clearance of infected red blood cells. With steady state hemoglobin concentrations that are typically in the rage of 6-8 g/dl, patients with SCA might also be vulnerable to the sudden onset of catastrophic anemia brought on by the hemolysis or ineffective erythropoeisis that is commonly associated with malaria infections ${ }^{35}$, and it seems likely that the tissue hypoxia and inflammatory processes that typically accompany malaria infection might be potent triggers of 'sequestration crises'. Nevertheless, clinical data relating to the relative risk of malaria and its consequences in patients with SCD is somewhat confusing.

Although malaria did not feature strongly in early descriptions of the natural history of $\mathrm{SCD}^{36,37}$, it was implicated as a significant problem in a number of later reports ${ }^{38-44}$. Nevertheless, while such reports confirmed that children with SCD can suffer from malaria infections, they shed no light on the relative risks or consequences of the disease in comparison to normal children. Moreover, given the perception that malaria can be dangerous in patients with SCD, malaria prophylaxis is prescribed in most SCD clinics in malaria-endemic areas making data from prospective cohort studies difficult to interpret. Through a birth cohort study conducted in Western Kenya, in which participants were tested retrospectively for SCD on completion of the study (reducing the bias of prophylactic treatment) it was shown that, while all-cause mortality was significantly higher among SCD 
than control children, the incidence rates of both severe malaria anemia and high density $P$. falciparum infections were lower in children with SCD than in normal children ${ }^{45}$. This suggests that children with SCD might enjoy a degree of resistance to $P$. falciparum infections but does not exclude the possibility that malaria infections might have been a precipitating event in some or all of those who died.

Intervention studies potentially offer a more robust approach to investigating the importance of malaria as a health problem in patients with SCD. A number of placebo-controlled trials of antimalarial prophylaxis have been conducted in patients with SCD, including two considered sufficiently robust to be included in a recent Cochrane review ${ }^{46}$. The authors concluded that malaria prophylaxis reduces the risks of sickle cell crises, blood transfusions and hospital admissions, and results in increased mean hemoglobin levels, all of which suggest that malaria is an important cause of ill health among children with SCD in many parts of Africa and that such children should be protected from the disease.

Although the literature on the relationship between malaria and SCD remains somewhat confusing, the following describes the most likely situation. SCD is associated with relative protective against the acquisition of $P$. falciparum infections, to a degree that may even be higher than that which is associated with HbAS. However, this protection is not complete, and when patients with SCD do become infected by malaria parasites the consequences can be catastrophic, through the precipitation of crises and the rapid development of severe anemia. With this in mind it seems highly likely that by diagnosing SCD through screening in early life and protecting affected children from malaria, the survival of children living with SCD in areas of high malaria transmission will be significantly improved. However, important questions still remain about the most appropriate strategies for malaria prevention. For example, should all malaria-exposed patients be prescribed prophylaxis throughout life, or is it possible that at lower levels of malaria transmission the risks of treatment might outweigh the risks of infection; with increasing resistance to antimalarial drugs and side effects from the long term use of some, which antimalarial drugs offer the best balance between risk and benefit; and might alternative approaches, such as intermittent presumptive treatment for malaria or transmission avoidance through methods such as impregnated bednets or indoor residual spraying of houses be more appropriate in areas of lower transmission? Definitive clinical trials are needed to address these important questions.

\section{Bacteremia}

Invasive bacterial infections are a second group of conditions that make a significant but unknown contribution to the high early mortality seen in African children with SCD. Children with SCD manifest a number of immunological abnormalities including decreased splenic function, reduced serum opsonin activity and abnormal neutrophil function, and it has long been known that children with SCA in the North are at very considerable risk of invasive bacterial infections, particularly those caused by capsulated organisms such as Streptococcus pneumoniae, Haemophilus influenzae, and non-Typhi Salmonella species $^{47-52}$. Early studies conducted in the North showed that the risk of invasive pneumococcal disease during early life was up to 50 fold higher in children with SCD compared to normal children, and the subsequent implementation of strategies such as 
pneumococcal vaccination and penicillin prophylaxis led to the virtual elimination of this excess risk in multiple populations in subsequent years ${ }^{47-52}$.

Despite being well documented in the North, data regarding the risks of bacteremia among patients with SCD in Africa have been slow to accumulate and subject to controversy. $S$. pneumoniae was the most common organism isolated from children with SCD in an early study conducted in the Congo ${ }^{15}$ but subsequent studies conducted in Uganda and Nigeria ${ }^{53-57}$ suggested that other organisms, particularly Staphylococcus aureus, Escherichia coli, Klebsiella spp. and non-Typhi Salmonella infections may be more important in the African context. In these studies, both $S$. pneumoniae and $H$. influenzae were found relatively infrequently ${ }^{53-58}$, leading some commentators to question the potential benefits of antimicrobial prophylaxis in African patients with $\mathrm{SCD}^{55,57,59}$. Nevertheless, most of these studies were open to misinterpretation, because serious bacterial infections have their peak incidence in very early childhood, while most of the African studies were conducted in older children who survived their early years to present with symptoms of SCD. Furthermore, organisms like $S$. pneumoniae and $H$. influenzae are considerably more fastidious and difficult to grow than some of these other organisms, and culture sensitivity may therefore have biased the distribution of the pathogens observed in some of these studies.

Despite this early confusion, it has now been shown beyond all doubt that, just like children with SCD born in the North, children born with SCD in Africa are at substantial risk of severe infections in early life and that the highest risks relate to the same pathogenic organisms: $S$. pneumoniae, $H$. influenzae, and non-Typhi Salmonella species ${ }^{60}$. Taking as a starting point over 1700 children who were diagnosed with bacteremia through the surveillance of all admissions to a general pediatric facility, it was shown through retrospective genotyping for SCD that young children with the condition were at very high risk of bacteremia from these top three organisms (1.2-5.0 episodes/100 person years), a risk that was similar to the that reported from developed countries (1.5-11.6) during the era before the introduction of antibiotic prophylaxis or pneumococcal vaccines ${ }^{47-52}$. A subsequent meta-analysis of available case-control studies conducted in African children showed that the risk of all-cause invasive bacterial infections was 19-times higher in children with SCD compared to normal children: 36-times higher for $S$. pneumoniae and 13-times higher for $H$. influenzae type $b^{61}$. Collectively these observations suggest that collectively, invasive bacterial diseases make a very significant contribution to the tremendous mortality associated with SCA in African children.

\section{The future of SCD in sub-Saharan Africa}

Despite the historically low priority that SCD has enjoyed throughout much of SSA, there are promising signs that the situation is now beginning to improve. SCD has recently been recognized as an important but neglected problem by a number of key agencies, including the United Nations ${ }^{62}$ and the World Health Organization ${ }^{63}$, and a rising number of research groups and governments are taking an increasingly active interest in the detection and management of the condition (Figure 2). Moreover, in recent years, pilot projects of newborn screening have been reported from a number of centres ${ }^{64-66}$, which suggest that, in 
principle, early detection is within the reach of many countries in the region. Because the highest rates of mortality are likely to occur in the first few years of life, establishing such services in areas with the highest prevalence of SCD will be key to reducing current levels of mortality in affected patients, and in many parts of Africa might also have a substantial effect on child mortality overall ${ }^{3}$. The gradual introduction of newborn screening for SCD in the United States and many parts of Europe in the last 40 years, coupled with the provision of a basic package of care (including vaccination for common bacterial infections and penicillin prophylaxis until at least 5 years of age), has led to a situation in which most children born with SCD in the North today can expect to live until their 40s and 50s ${ }^{29-31}$. However, as discussed below, to assume that similar advances could be achieved in most parts of Africa without substantial education programs, the careful fostering of political will, and significant financial investment, would be over-simplistic.

\section{Bottlenecks in the care of SCD in sub-Saharan Africa}

Unlike the North, where newborn screening programs for SCD and a wide range of other genetic conditions have been implemented for many years, in most parts of SSA the infrastructure for screening is simply not available. Moreover, in many African communities, SCD is associated with significant stigmatization to which the mothers of affected children can be particularly vulnerable ${ }^{67-69}$. Screening for the condition can precipitate disharmony, which at times can include domestic violence and the breakdown of marriages ${ }^{67-69}$. Careful consideration of such issues should therefore be a pre-requisite to the implementation of newborn screening programs within the region. Even beyond the anthropological issues, establishing such programs is non-trivial and involves the development of efficient methods for the transport of samples from testing sites (such as mother and child health clinics) to well-resourced reference laboratories with reliable facilities for the storage and testing of samples, and efficient methods for the tracing, follow-up and confirmatory testing of affected babies. An effective system requires computer-based record keeping, a sufficient number of well-trained staff to conduct all functions, reliable power supply and other elements that make the cost-implications of screening substantial. Careful cost-benefit analyses and considerable advocacy will be required before African governments begin to establish such programs at national scale. Nevertheless, several countries in the region are heading in the right direction. For example, in partnership with the government of Brazil, Ghana is moving towards a national newborn screening program for SCD, and discussions regarding a national strategy for SCD are also underway in Tanzania ${ }^{70}$.

Even without newborn screening, with progressive epidemiological and demographic transition, and the roll-out of an increasing range of newborn vaccines (including those for $S$. pneumoniae and $H$. influenzae) in many countries within the region, it is inevitable that an increasing number of children born with SCD in SSA will survive and require appropriate treatment. The implications of this emerging epidemic for health systems in SSA may well be considerable. As SCD transitions from a condition that is fatal in early life to a chronic condition needing life-long care, health services will come under increasing pressure to provide appropriate preventive and curative services. Moreover, this transition will come with substantial implications for families of affected children, who will face increasing pressures from issues that will include the considerable financial and emotional costs that 
can result from medical fees, to the inability to maintain income-generating activities on account of the high levels of child-care that will be required ${ }^{67}$. Blood transfusion services are one area that will face increasing pressure: patients with SCD are significant recipients of emergency transfusions and with longer-term survival and increased use of transfusion therapy they will be not only the recipients of a growing proportion of available supplies but also with repeated transfusions will be vulnerable to transfusion-acquired infections and to allo-immunization ${ }^{71}$. Without appropriate monitoring through trans-cranial Doppler ${ }^{\mathrm{TM}}$ (TCD) ultrasonography coupled with lack of access to chronic blood transfusion or hydroxyurea therapy in the event of an abnormal TCD result, an increasing proportion of African patients with SCD will develop acute and chronic cerebro-vascular events, with significantly impacts on their quality of life ${ }^{72}$. Finally, without appropriate monitoring and treatment, patients with SCD will also suffer an increased burden of many of the other chronic consequences of the condition including mental health issues and depression ${ }^{73,74}$, chronic pulmonary disease, renal failure, chronic bone diseases and ocular complications ${ }^{2}$. Given the virtual absence of data regarding the age-specific incidence of any of these complications from studies conducted anywhere in Africa, it is impossible to predict the precise burden of any of these sequelae going forward; however, the logic of simple arithmetic tells us that in the absence of specific treatments, these chronic complications of SCD will have major implications for African societies and health systems in the years ahead.

\section{Future priorities for SCD in Africa}

Given the demands that the growing number of patients living with SCD will increasingly place on African health systems in future, it is essential that clinicians, researchers, Health Ministries and international organizations begin to consider the priority questions with increasing urgency. Describing the number of patients affected, estimating survival and complication rates with greater precision must be an early priority for research in the next few years. While recent estimates provide an excellent starting point ${ }^{75,76}$, much of the data on which they estimates were based are out of date, and are too sparse to be sufficiently useful at local level. Better estimates from larger-scale contemporary studies would be more meaningful to the health planners whose responsibly it is to make decisions regarding priorities for health spending and the allocation of scarce resources. These planners will also benefit from cost-economic estimates regarding various approaches to diagnosis and treatment. Further, it is likely that such data would be most influential if the end-users particularly national ministries of health - were engaged from the outset. As described above, the current need for quality-controlled, centralized diagnostic services is beyond the reach of many countries in SSA and the development of reliable, cheap, point-of-care methods for the diagnosis of SCD that could also be used for newborn screening, could revolutionize the management of patients with SCD in Africa, and would also benefit studies designed to refine our estimates of its distribution. A number of such devices are under development and show considerable promise. Finally, a clear understanding of the sociological and anthropological issues surrounding SCD in different societies ${ }^{67-69}$ will be important going forwards, and may influence decisions about local policies with regard to diagnosis and treatment. 


\section{Specific treatments for SCD in SSA}

Beyond the standard treatments that will continue to be needed for the prevention of malaria and bacterial infections, the long-term consequences of $\mathrm{SCD}^{2}$ will place an increasing burden on African societies without the wide-spread implementation of disease-modifying therapies. For the time being, hydroxyurea (also known as hydroxycarbamide), the only disease-modifying agent that is currently licensed for the treatment of SCD in the North, represents perhaps the only current viable option for Africa in this regard. Nevertheless, despite its well-documented benefits among both adults and children in the North ${ }^{77-79}$, legitimate questions surround the potential risks and benefits of hydroxyurea for the treatment of patients with SCD in Africa. Hydroxyurea is an oral medication with excellent bioavailability, but is associated with variable pharmacokinetics and pharmacodynamics ${ }^{80}$. Although its therapeutic mechanisms in SCD are incompletely understood, they appear to relate to a number of actions including the promotion of fetal hemoglobin production and reductions in the inflammatory response ${ }^{81}$. As a potent inhibitor of ribonucleotide reductase, hydroxyurea is both cytotoxic and myelo-suppressive ${ }^{82}$, and treatment is associated with reversible reductions in the production of all blood cell lineages. This predictable effect of hydroxyurea relates to its therapeutic benefit, and for each specific patient on treatment, the daily dose must be titrated against these reductions until the "maximum tolerated dose" (MTD) is reached ${ }^{83}$. Although hydroxyurea is increasingly being used in the ad-hoc management of patients with SCA in many parts of sub-Saharan Africa ${ }^{84}$, no consensus management guidelines have yet been established and no prospective clinical trials have yet been performed to ensure that the treatment is equally safe and effective in the African context ${ }^{84}$. Given that the safe use of hydroxyurea requires titration of dosing and frequent laboratory monitoring to evaluate potential hematological toxicities, it is critical to prospectively evaluate hydroxyurea in various settings across SSA in order to establish local dosing and monitoring guidelines. In many parts of sub-Saharan Africa capacity for this kind of monitoring is limited, and the costs lead to questions of affordability ${ }^{85}$. Moreover, the infectious disease exposure (including bacterial diseases and malaria) and reduced nutritional status of children living with SCA in many parts of SSA present additional challenges for the initiation and maintenance of hydroxyurea therapy. Nevertheless, if hydroxyurea was proven to be both safe and effective for children with SCA in SSA, it could realistically emerge as the main disease-modifying therapeutic intervention to help improve the health of children born with SCA on the continent. A number of clinical trials are currently underway in various parts of SSA Africa that will hopefully begin to answer this question, including one ambitious trial (Realizing Effectiveness Across Continents with Hydroxyurea: REACH) that is studying the safety and effectiveness of hydroxyurea in Angola, the Demographic Republic of Congo, Uganda and Kenya (NCT01966731) (https:// clinicaltrials.gov/ct2/show/record/NCT01966731) ${ }^{86}$.

The only other option with obvious potential for modifying the course of SCD among patients in Africa is transfusion therapy. Transfusion therapy has played a pivotal role in the management of SCD in the North, most notably in the primary prevention strokes in patients with abnormal TCD velocities ${ }^{87,88}$ and through improved oxygenation in patients presenting with the acute chest syndrome (ACS) ${ }^{89}$. Transfusion therapy may also be more effective in 
reducing the incidence of both painful crises and ACS than other treatments ${ }^{90,91}$. Nevertheless, despite these well-recognized benefits, transfusion therapy can result in iron overload, and should therefore be used in conjunction with iron-monitoring and chelation therapy. Moreover, regular transfusions come with the additional risk of alloimmunization (an even greater risk in SSA where most blood for transfusion is not leuco-depleted), transfusion-acquired infections, issues related to venous access such as thrombosis and linerelated sepsis, and loss of work and schooling ${ }^{92}$. Even in the North, the total economic costs of transfusion therapy far exceed those of treatment with hydroxyurea ${ }^{93,94}$, and it is therefore reserved for a limited number of specific indications. Together, these considerations make transfusion therapy unrealistic for the vast majority of patients living in Africa.

Finally, the only curative treatment that is currently available for SCD is allogeneic hemopoietic stem-cell transplantation (HSCT) ${ }^{95}$. Successful HSCT can result in disease-free survival and stabilization of neurological lesions. However, even in the North, the variable and unpredictable severity of SCD mean that HSCT is reserved for the most severely affected patients ${ }^{96}$, and the fine balance between the risks and benefits of treatment, including long-term toxicities such as infertility and endocrinopathies ${ }^{97}$ and a failure rate of $10-15 \% 95$, make the decision to proceed to HSCT complex. While HSCT has been advocated as a viable option for African patients with SCD by some experts ${ }^{98}$, given the issues of benefit versus harm, the limited facilities and infrastructure for HSCT in the region, and the likely costs, investment in HSCT does not seem an immediate priority.

\section{Summary}

Given the enormous current and future burden of SCD in SSA, and the contribution that it makes to total child mortality, the condition has been historically neglected. In recent years some progress has been made in reversing this situation; however, substantial investments will be required to move SCD up the agenda to its rightful place as a priority disease for African governments going forwards. Some key areas for future work include better and more up-to-date descriptions of the burden of SCD at local scale and studies of the natural history of SCD among patients in SSA who are on routine treatment, with a particular emphasis on describing the incidence of the acute and chronic complications of the disease in the African context. While wide-spread programs for the early diagnosis and treatment of SCD in SSA could yield substantial benefits for patients and their families, a great deal more needs to be known about the local anthropological and social attitudes to SCD, and steps need to be taken to mitigate against any adverse consequences for affected populations. Health-care planners will need to be convinced of the benefits of a greater focus on SCD through cost-economic analyses of various approaches to diagnosis and treatment. Beyond descriptions of the disease, there is a clear need for clinical trials aimed at addressing a wide range of issues including optimal approaches to the prevention of bacterial infections and malaria, strategies in the area of blood transfusion and blood safety, and trials of diseasemodifying treatments including hydroxyurea. Underlying all of the above must be the principle that not all of the lessons that have been learnt about SCD from studies conducted in the North during the last 60 years will be appropriate or applicable to Africa. Forward 
planning will best be informed by extensive research on all aspects of SCD in the African context.

\section{References}

1. Murayama M. Structure of sickle cell hemoglobin and molecular mechanism of the sickling phenomenon. Clin Chem. 1967; 13(7):578-88. [PubMed: 4952917]

2. Rees DC, Williams TN, Gladwin MT. Sickle-cell disease. Lancet. 2010; 376(9757):2018-31. [PubMed: 21131035]

3. Modell B, Darlison M. Global epidemiology of haemoglobin disorders and derived service indicators. Bull World Health Organ. 2008; 86(6):480-7. [PubMed: 18568278]

4. Weatherall, DJ, Clegg, JB. The thalassaemia syndromes. 3rd ed. Oxford: Blackwell Scientific Publications; 2002.

5. Kulozik AE, Wainscoat JS, Serjeant GR, et al. Geographical survey of beta S-globin gene haplotypes: evidence for an independent Asian origin of the sickle-cell mutation. Am J Hum Genet. 1986; 39(2):239-44. [PubMed: 3752087]

6. Flint J, Harding RM, Boyce AJ, Clegg JB. The population genetics of the haemoglobinopathies. Baillieres Clin Haematol. 1998; 11(1):1-51. [PubMed: 10872472]

7. Piel FB, Patil AP, Howes RE, et al. Global distribution of the sickle cell gene and geographical confirmation of the malaria hypothesis. Nat Commun. 2010; 1(8):104. [PubMed: 21045822]

8. Allison AC. Protection afforded by sickle cell trait against subtertian malarial infection. British Medical Journal. 1954; 1:290-5. [PubMed: 13115700]

9. Williams TN. Human red blood cell polymorphisms and malaria. Curr Opin Microbiol. 2006; 9(4): 388-94. [PubMed: 16815736]

10. Taylor SM, Parobek CM, Fairhurst RM. Haemoglobinopathies and the clinical epidemiology of malaria: a systematic review and meta-analysis. Lancet Infect Dis. 2012; 12(6):457-68. [PubMed: 22445352]

11. The Malaria Genomic Epidemiology Network. Reappraisal of known malaria resistance loci in a large multicenter study. Nature Genetics. 2014; 46(11):1197-204. [PubMed: 25261933]

12. Kreuels B, Kreuzberg C, Kobbe R, et al. Differing effects of $\mathrm{HbS}$ and $\mathrm{HbC}$ traits on uncomplicated falciparum malaria, anemia, and child growth. Blood. 2010; 115(22):4551-8. [PubMed: 20231425]

13. Nyakeriga AM, Troye-Blomberg M, Chemtai AK, Marsh K, Williams TN. Malaria and nutritional status in children living on the coast of Kenya. Am J Clin Nutr. 2004; 80(6):1604-10. [PubMed: 15585775]

14. Scott JA, Berkley JA, Mwangi I, et al. Relation between falciparum malaria and bacteraemia in Kenyan children: a population-based, case-control study and a longitudinal study. Lancet. 2011; 378(9799):1316-23. [PubMed: 21903251]

15. Eeckels R, Gatti F, Renoirte AM. Abnormal distribution of haemoglobin genotypes in Negro children with severe bacterial infections. Nature. 1967; 216(113):382. [PubMed: 6053819]

16. Friedman MJ. Erythrocytic mechanism of sickle cell resistance to malaria. Proc Natl Acad Sci U S A. 1978; 75(4):1994-7. [PubMed: 347452]

17. Friedman MJ, Roth EF, Nagel RL, Trager W. The role of hemoglobins C, S, and Nbalt in the inhibition of malaria parasite development in vitro. Am J Trop Med Hyg. 1979; 28(5):777-80. [PubMed: 384816]

18. Pasvol G, Weatherall DJ, Wilson RJ. Cellular mechanism for the protective effect of haemoglobin S against $P$. falciparum malaria. Nature. 1978; 274(5672):701-3. [PubMed: 353566]

19. Fairhurst RM, Fujioka H, Hayton K, Collins KF, Wellems TE. Aberrant development of Plasmodium falciparum in hemoglobin CC red cells: implications for the malaria protective effect of the homozygous state. Blood. 2003; 101(8):3309-15. [PubMed: 12480691]

20. Cholera R, Brittain NJ, Gillrie MR, et al. Impaired cytoadherence of Plasmodium falciparuminfected erythrocytes containing sickle hemoglobin. Proc Natl Acad Sci U S A. 2008; 105(3):9916. [PubMed: 18192399] 
21. Fairhurst RM, Baruch DI, Brittain NJ, et al. Abnormal display of PfEMP-1 on erythrocytes carrying haemoglobin C may protect against malaria. Nature. 2005; 435(7045):1117-21. [PubMed: 15973412]

22. Ayi K, Turrini F, Piga A, Arese P. Enhanced phagocytosis of ring-parasitized mutant erythrocytes. A common mechanism that may explain protection against falciparum-malaria in sickle-trait and beta-thalassemia-trait. Blood. 2004; 104:3364-71. [PubMed: 15280204]

23. Luzzatto L, Nwachuku-Jarrett ES, Reddy S. Increased sickling of parasitised erythrocytes as mechanism of resistance against malaria in the sickle-cell trait. Lancet. 1970; 1(7642):319-21. [PubMed: 4189578]

24. Roth EF Jr, Friedman M, Ueda Y, Tellez I, Trager W, Nagel RL. Sickling rates of human AS red cells infected in vitro with Plasmodium falciparum malaria. Science. 1978; 202(4368):650-2. [PubMed: 360396]

25. Shear HL, Roth EF Jr, Fabry ME, et al. Transgenic mice expressing human sickle hemoglobin are partially resistant to rodent malaria. Blood. 1993; 81(1):222-6. [PubMed: 8417791]

26. Herrick JB. Peculiar elongated and sickle-shaped red blood corpuscles in a case of severe anemia. Arch Intern Med. 1910; 6(5):517-21.

27. Lehmann H, Raper AB. Maintenance of high sickling rate in an African community. Br Med J. 1956; 2(4988):333-6. [PubMed: 13342481]

28. Grosse SD, Odame I, Atrash HK, Amendah D, Piel FB, Williams TN. Sickle cell disease in Africa: a neglected cause of early child mortality. Am J Prev Med. 2011

29. Telfer P, Coen P, Chakravorty S, et al. Clinical outcomes in children with sickle cell disease living in England: a neonatal cohort in East London. Haematologica. 2007; 92(7):905-12. [PubMed: 17606440]

30. Quinn CT, Rogers ZR, McCavit TL, Buchanan GR. Improved survival of children and adolescents with sickle cell disease. Blood. 2010; 115(17):3447-52. [PubMed: 20194891]

31. Wierenga KJ, Hambleton IR, Lewis NA. Survival estimates for patients with homozygous sicklecell disease in Jamaica: a clinic-based population study. Lancet. 2001; 357(9257):680-3. [PubMed: 11247552]

32. Piel FB, Patil AP, Howes RE, et al. Global epidemiology of sickle haemoglobin in neonates: a contemporary geostatistical model-based map and population estimates. Lancet. 2012

33. Williams TN, Mwangi TW, Wambua S, et al. Negative epistasis between the malaria-protective effects of $\mathrm{a}^{+}$-thalassemia and the sickle cell trait. Nat Genet. 2005; 37:1253-7. [PubMed: 16227994]

34. Pasvol G, Weatherall D, Wilson RJM. The increased susceptibility of young red cells to invasion by the malaria parasite Plasmodium falciparum. Br J Haematol. 1980; 45:285-95. [PubMed: 7002199]

35. Lamikanra AA, Brown D, Potocnik A, Casals-Pascual C, Langhorne J, Roberts DJ. Malarial anemia: of mice and men. Blood. 2007; 110(1):18-28. [PubMed: 17341664]

36. Trowell HC, Raper AB, Welbourn HF. The natural history of homozygous sickle-cell anaemia in Central Africa. Q J Med. 1957; 26(104):401-22. [PubMed: 13494689]

37. Lambotte-Legrand J, Lambotte-Legrand C. Le prognostic de l'anemie drepanocytaire au Congo Belge (a propos de 300 case et de 150 deces). Ann Soc Belg Med Trop. 1955; 35:53-7.

38. Adeloye A, Luzzatto L, Edington GM. Severe malarial infection in a patient with sickle-cell anaemia. Br Med J. 1971; 2(759):445-6. [PubMed: 5576007]

39. Konotey-Ahulu FI. Malaria and sickle-cell disease. Br Med J. 1971; 2(763):710-1.

40. Seymour A. Malaria and sickle cell disease. Br Med J. 1971; 2(763):711.

41. Pichanick AM. Severe malarial infection. Br Med J. 1971; 3(766):114.

42. Ambe JP, Fatunde JO, Sodeinde OO. Associated morbidities in children with sickle-cell anaemia presenting with severe anaemia in a malarious area. Trop Doct. 2001; 31(1):26-7. [PubMed: 11205596]

43. Ibidapo MO, Akinyanju OO. Acute sickle cell syndromes in Nigerian adults. Clin Lab Haematol. 2000; 22(3):151-5. [PubMed: 10931163] 
44. Okuonghae HO, Nwankwo MU, Offor E. Malarial parasitaemia in febrile children with sickle cell anaemia. J Trop Pediatr. 1992; 38(2):83-5. [PubMed: 1569641]

45. Aidoo M, Terlouw DJ, Kolczak MS, et al. Protective effects of the sickle cell gene against malaria morbidity and mortality. Lancet. 2002; 359(9314):1311-2. [PubMed: 11965279]

46. Oniyangi O, Omari AA. Malaria chemoprophylaxis in sickle cell disease. Cochrane Database Syst Rev. 2006; (4)

47. Wollstein M, Kreidel KV. Sickle cell anemia. Am J Dis Child. 1928; 36:998-1011.

48. Robinson MG, Watson RJ. Pneumococcal meningitis in sickle-cell anemia. N Engl J Med. 1966; 274(18):1006-8. [PubMed: 5909733]

49. Barrett-Connor E. Bacterial infection and sickle cell anemia. An analysis of 250 infections in 166 patients and a review of the literature. Medicine (Baltimore). 1971; 50(2):97-112. [PubMed: 4944120]

50. Lobel JS, Bove KE. Clinicopathologic characteristics of septicemia in sickle cell disease. Am J Dis Child. 1982; 136(6):543-7. [PubMed: 7091069]

51. Powars D, Overturf G, Turner E. Is there an increased risk of Haemophilus influenzae septicemia in children with sickle cell anemia? Pediatrics. 1983; 71(6):927-31. [PubMed: 6602325]

52. Diggs LW. Bone and joint lesions in sickle-cell disease. Clin Orthop. 1967; 52:119-43. [PubMed: 6048904]

53. Akinyanju O, Johnson AO. Acute illness in Nigerian children with sickle cell anaemia. Ann Trop Paediatr. 1987; 7(3):181-6. [PubMed: 2445266]

54. Okuonghae HO, Nwankwo MU, Offor EC. Pattern of bacteraemia in febrile children with sickle cell anaemia. Ann Trop Paediatr. 1993; 13(1):55-64. [PubMed: 7681646]

55. Akuse RM. Variation in the pattern of bacterial infection in patients with sickle cell disease requiring admission. J Trop Pediatr. 1996; 42(6):318-23. [PubMed: 9009554]

56. Aken'ova YA, Bakare RA, Okunade MA. Septicaemia in sickle cell anaemia patients: the Ibadan experience. Cent Afr J Med. 1998; 44(4):102-4. [PubMed: 9810403]

57. Kizito ME, Mworozi E, Ndugwa C, Serjeant GR. Bacteraemia in homozygous sickle cell disease in Africa: is pneumococcal prophylaxis justified? Arch Dis Child. 2007; 92(1):21-3. [PubMed: 16531454]

58. Makani J, Mgaya J, Balandya E, et al. Bacteraemia in sickle cell anaemia is associated with low haemoglobin: a report of 890 admissions to a tertiary hospital in Tanzania. Br J Haematol. 2015

59. Serjeant GR. Mortality from sickle cell disease in Africa. Bmj. 2005; 330(7489):432-3. [PubMed: 15731125]

60. Williams TN, Uyoga S, Macharia A, et al. Bacteraemia in Kenyan children with sickle-cell anaemia: a retrospective cohort and case-control study. Lancet. 2009; 374(9698):1364-70. [PubMed: 19747721]

61. Ramakrishnan M, Moisi JC, Klugman KP, et al. Increased risk of invasive bacterial infections in African people with sickle-cell disease: a systematic review and meta-analysis. Lancet Infect Dis. 2010; 10(5):329-37. [PubMed: 20417415]

62. United Nations press office. Press conference on raising awareness of sickle-cell anaemia. 2009. http://www.un.org/News/briefings/docs/2009/090619_Anaemia.doc.htm

63. World Health Organization Regional Office for Africa. Sickle-cell disease: a strategy for the WHO African Region. Report of the Regional Director. 2010

64. Tshilolo L, Aissi LM, Lukusa D, et al. Neonatal screening for sickle cell anaemia in the Democratic Republic of the Congo: experience from a pioneer project on 31204 newborns. J Clin Pathol. 2009; 62(1):35-8. [PubMed: 19103857]

65. Kafando E, Nacoulma E, Ouattara Y, et al. Neonatal haemoglobinopathy screening in Burkina Faso. J Clin Pathol. 2009; 62(1):39-41. [PubMed: 19103858]

66. McGann PT, Ferris MG, Ramamurthy U, et al. A prospective newborn screening and treatment program for sickle cell anemia in Luanda, Angola. Am J Hematol. 2013; 88(12):984-9. [PubMed: 24038490] 
67. Marsh VM, Kamuya DM, Molyneux SS. 'All her children are born that way': gendered experiences of stigma in families affected by sickle cell disorder in rural Kenya. Ethn Health. 2011; 16(4-5): 343-59. [PubMed: 21797722]

68. Assimadi JK, Gbadoe AD, Nyadanu M. [The impact on families of sickle cell disease in Togo]. Arch Pediatr. 2000; 7(6):615-20. [PubMed: 10911527]

69. Bamisaiye A, Bakare CG, Olatawura MO. Some social-psychologic dimensions of sickle cell anemia among Nigerians. Clin Pediatr (Phila). 1974; 13(1):56-9. [PubMed: 4809613]

70. Makani J, Soka D, Rwezaula S, et al. Health policy for sickle cell disease in Africa: experience from Tanzania on interventions to reduce under-five mortality. Trop Med Int Health. 2015; 20(2): 184-7. [PubMed: 25365928]

71. Dzik WS, Kyeyune D, Otekat G, et al. Transfusion Medicine in Sub-Saharan Africa: Conference Summary. Transfus Med Rev. 2015; 29(3):195-204. [PubMed: 25752939]

72. Ohene-Frempong K, Weiner SJ, Sleeper LA, et al. Cerebrovascular accidents in sickle cell disease: rates and risk factors. Blood. 1998; 91(1):288-94. [PubMed: 9414296]

73. Lukoo RN, Ngiyulu RM, Mananga GL, et al. Depression in children suffering from sickle cell anemia. J Pediatr Hematol Oncol. 2015; 37(1):20-4. [PubMed: 25354254]

74. Ohaeri JU, Shokunbi WA, Akinlade KS, Dare LO. The psychosocial problems of sickle cell disease sufferers and their methods of coping. Soc Sci Med. 1995; 40(7):955-60. [PubMed: 7792634]

75. Piel FB, Hay SI, Gupta S, Weatherall DJ, Williams TN. Global burden of sickle cell anaemia in children under five, 2010-2050: modelling based on demographics, excess mortality, and interventions. Plos Med. 2013; 10(7):e1001484. [PubMed: 23874164]

76. Piel FB, Tatem AJ, Huang Z, Gupta S, Williams TN, Weatherall DJ. Global migration and the changing distribution of sickle haemoglobin: a quantitative study of temporal trends between 1960 and 2000. The Lancet Global health. 2014; 2(2):e80-9. [PubMed: 24748392]

77. Charache S, Terrin ML, Moore RD, et al. Effect of hydroxyurea on the frequency of painful crises in sickle cell anemia. Investigators of the Multicenter Study of Hydroxyurea in Sickle Cell Anemia. The New England journal of medicine. 1995; 332(20):1317-22. [PubMed: 7715639]

78. Kinney TR, Helms RW, O'Branski EE, et al. Safety of hydroxyurea in children with sickle cell anemia: results of the HUG-KIDS study, a phase I/II trial. Pediatric Hydroxyurea Group. Blood. 1999; 94(5):1550-4. [PubMed: 10477679]

79. Wang WC, Ware RE, Miller ST, et al. Hydroxycarbamide in very young children with sickle-cell anaemia: a multicentre, randomised, controlled trial (BABY HUG). Lancet. 2011; 377(9778): 1663-72. [PubMed: 21571150]

80. Ware RE, Despotovic JM, Mortier NA, et al. Pharmacokinetics, pharmacodynamics, and pharmacogenetics of hydroxyurea treatment for children with sickle cell anemia. Blood. 2011; 118(18):4985-91. [PubMed: 21876119]

81. Platt OS, Orkin SH, Dover G, Beardsley GP, Miller B, Nathan DG. Hydroxyurea enhances fetal hemoglobin production in sickle cell anemia. J Clin Invest. 1984; 74(2):652-6. [PubMed: 6205021]

82. Lewis WH, Wright JA. Altered ribonucleotide reductase activity in mammalian tissue culture cells resistant to hydroxyurea. Biochem Biophys Res Commun. 1974; 60(3):926-33. [PubMed: 4429567]

83. Ware RE. How I use hydroxyurea to treat young patients with sickle cell anemia. Blood. 2010; 115(26):5300-11. [PubMed: 20223921]

84. Mulaku M, Opiyo N, Karumbi J, Kitonyi G, Thoithi G, English M. Evidence review of hydroxyurea for the prevention of sickle cell complications in low-income countries. Arch Dis Child. 2013; 98(11):908-14. [PubMed: 23995076]

85. Galadanci NA, Abdullahi SU, Tabari MA, et al. Primary stroke prevention in Nigerian children with sickle cell disease (SPIN): challenges of conducting a feasibility trial. Pediatric blood \& cancer. 2015; 62(3):395-401. [PubMed: 25399822]

86. [accessed 23rd July 2015] 2015. https://clinicaltrials.gov/ct2/show/record/NCT01966731 
87. Adams RJ, McKie VC, Hsu L, et al. Prevention of a first stroke by transfusions in children with sickle cell anemia and abnormal results on transcranial Doppler ultrasonography. N Engl J Med. 1998; 339(1):5-11. [PubMed: 9647873]

88. Adams RJ, Brambilla D, Optimizing Primary Stroke Prevention in Sickle Cell Anemia Trial I. Discontinuing prophylactic transfusions used to prevent stroke in sickle cell disease. The New England journal of medicine. 2005; 353(26):2769-78. [PubMed: 16382063]

89. Vichinsky EP, Neumayr LD, Earles AN, et al. Causes and outcomes of the acute chest syndrome in sickle cell disease. National Acute Chest Syndrome Study Group. The New England journal of medicine. 2000; 342(25):1855-65. [PubMed: 10861320]

90. Miller ST, Wright E, Abboud M, et al. Impact of chronic transfusion on incidence of pain and acute chest syndrome during the Stroke Prevention Trial (STOP) in sickle-cell anemia. The Journal of pediatrics. 2001; 139(6):785-9. [PubMed: 11743502]

91. Alvarez O, Yovetich NA, Scott JP, et al. Pain and other non-neurological adverse events in children with sickle cell anemia and previous stroke who received hydroxyurea and phlebotomy or chronic transfusions and chelation: results from the SWiTCH clinical trial. American journal of hematology. 2013; 88(11):932-8. [PubMed: 23861242]

92. Chou ST. Transfusion therapy for sickle cell disease: a balancing act. Hematology / the Education Program of the American Society of Hematology American Society of Hematology Education Program. 2013; 2013:439-46.

93. Wayne AS, Schoenike SE, Pegelow CH. Financial analysis of chronic transfusion for stroke prevention in sickle cell disease. Blood. 2000; 96(7):2369-72. [PubMed: 11001885]

94. Wang WC, Oyeku SO, Luo Z, et al. Hydroxyurea is associated with lower costs of care of young children with sickle cell anemia. Pediatrics. 2013; 132(4):677-83. [PubMed: 23999955]

95. Locatelli F, Pagliara D. Allogeneic hematopoietic stem cell transplantation in children with sickle cell disease. Pediatric blood \& cancer. 2012; 59(2):372-6. [PubMed: 22544533]

96. Chakravorty S, Williams TN. Sickle cell disease: a neglected chronic disease of increasing global health importance. Arch Dis Child. 2014

97. Dallas MH, Triplett B, Shook DR, et al. Long-term outcome and evaluation of organ function in pediatric patients undergoing haploidentical and matched related hematopoietic cell transplantation for sickle cell disease. Biol Blood Marrow Transplant. 2013; 19(5):820-30. [PubMed: 23416852]

98. Pule G, Wonkam A. Treatment for sickle cell disease in Africa: should we invest in haematopoietic stem cell transplantation? The Pan African medical journal. 2014; 18:46. [PubMed: 25368735] 


\section{Key Points}

- Sickle cell disease is a common and growing health problem in many parts of sub-Saharan Africa (SSA), where at least 240,000 affected children are born with the condition every year.

- $\quad$ Sickle cell disease is widely neglected on the continent, where an estimated $50-90 \%$ of those born with the condition die undiagnosed before their $5^{\text {th }}$ birthday.

- An unknown, but probably large proportion of these deaths are almost certainly attributable to two main conditions - malaria and invasive bacterial infections.

- With economic and public health advancements in many parts of the region, survival of affected children will likely improve, and lead to a growing need for appropriate medical services.

- $\quad$ Research into the issues surrounding sickle cell disease that are specific to SSA lags far behind that in North America and Europe, where there has been significant investment in recent decades.

- A greater emphasis on basic and applied research in the area of sickle cell disease in SSA could lead to substantial improvements to the lives and livelihoods of millions of those affected and their families. 


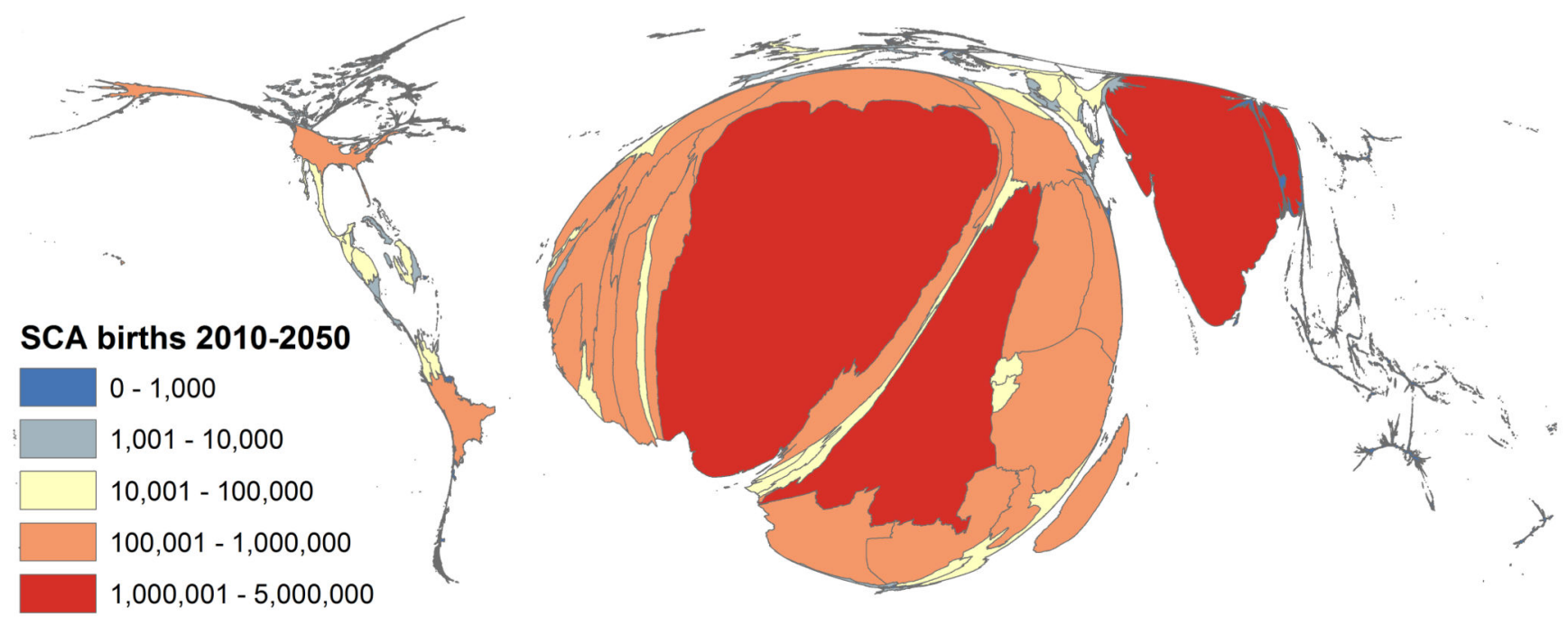

Figure 1. The global distribution of sickle cell anemia

Cartogram showing the global distribution of SCD SS, with the size of countries scaled to the number of annual births. Reproduced from Piel, FB et al, Plos Med 2013; 10(7): e1001484. 


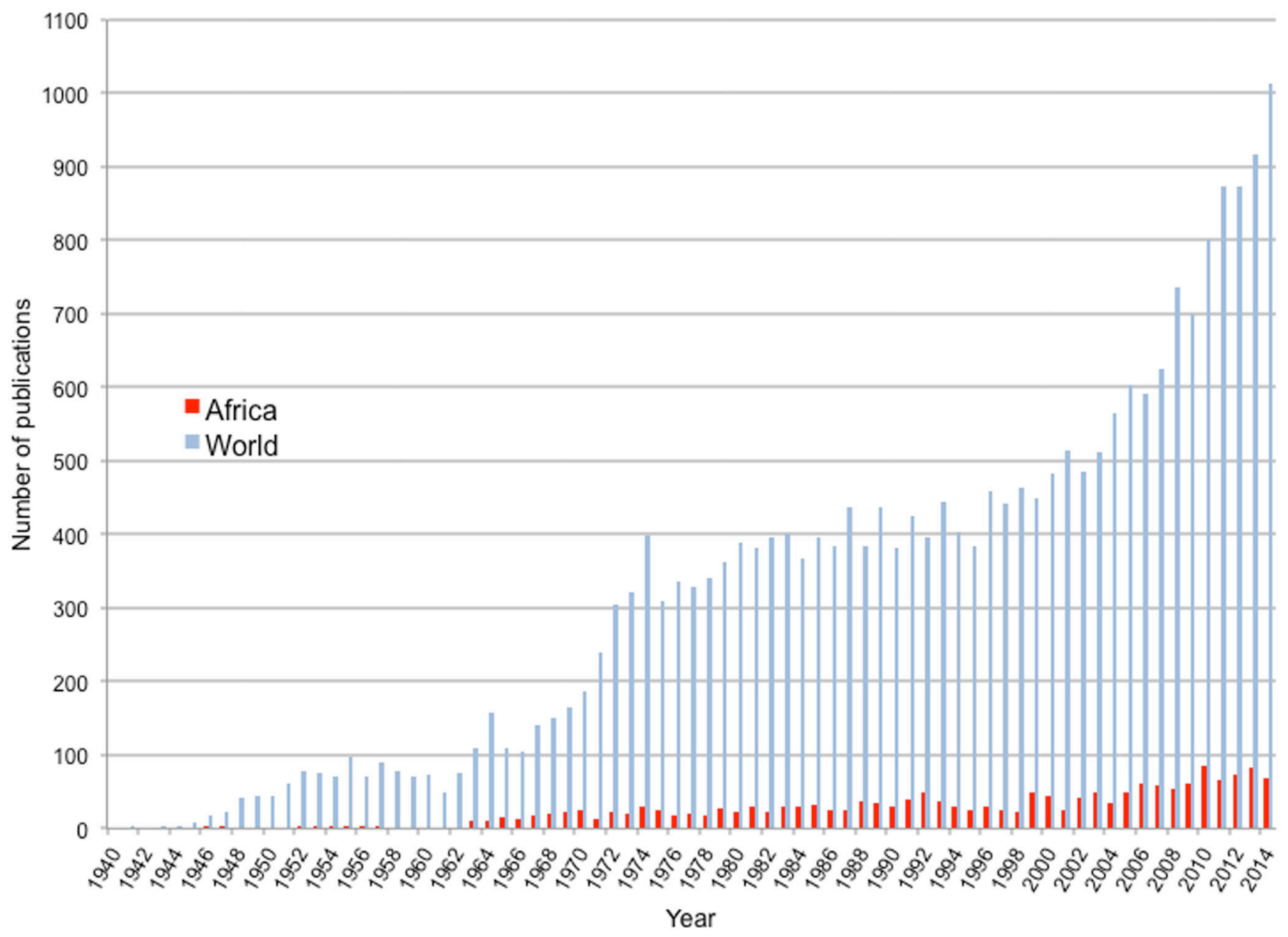

Figure 2. Number of publications per year mentioning sickle for the world and for Africa Graph shows the number of papers published per year detected by a search PubMed search under the terms "sickle" (global papers) and "sickle AND Africa" (papers from Africa). The numbers returned are maximum estimates as they also include papers on sickle cell trait. 